\title{
Methodology for Calculating the Reproduction Value of Buildings
}

\author{
Eduard Hromada ${ }^{1}$, Renáta Schneiderová Heralová ${ }^{1}$, Petr Dlask ${ }^{1}$, and Tomáš Krulický ${ }^{2}$ \\ ${ }^{1}$ Czech Technical University in Prague, Faculty of Civil Engineering, Thákurova 7, Prague 6, Czech \\ Republic \\ ${ }^{2}$ VŠTE, Okružní 517/10, České Budějovice, Czech Republic
}

\begin{abstract}
The article deals with the description of the methodology for calculating the reproduction value of buildings. It is a mathematical model that uses data obtained from a statistical survey and calculates the total reproduction value of buildings from a large data set. The model works with many variable inputs that describe the valued building. These include, for example, the use of the building, the enclosed space of the building, the floor area of the building, the building material of the supporting structures of the building, the age of the building, the technical condition of the building, the year the building was acquired and others. Based on the results, the model was calibrated and its parameters optimized to achieve the most accurate values.
\end{abstract}

Keywords: real estate market, real estate valuation, building wear, statistics

\section{Introduction}

Real estate valuation is one of the basic building blocks of the valuation issue which by its nature lies on the border between economics and other technical fields (construction, engineering, ...). Many authors focus on real estate valuation individually and deal with methods and approaches of valuing just one specific real estate. However, these methods fail in the valuation tasks of a statistically significant and internally inhomogeneous set of real estate, numbering several tens of thousands of units. When valuing such large sets of real estate, it is necessary to slightly modify the methods focused on the valuation of individual real estates and to adapt them to the possibilities of the appraiser. In the case of a valued group of several tens or hundreds of thousands of properties, it is basically unthinkable to perform selected valuation acts, such as local surveys etc. The presented article withdraws from this established practice and aims to determine the reproduction value of a large internally inhomogeneous set of real estate.

For this purpose, a set of a total of 50,000 properties will be examined, containing only buildings (excluding land) in the Czech Republic. The actual calculation of the reproduction value will be performed in two variants, both considering and not considering the ancillary budget costs, i.e. the costs expected to be invested for the acquisition of the construction. 


\section{Literary Research}

Real estate valuation is still a very topical issue to be solved in the field of expertise and valuation. This is an area where innovation is constantly taking place, from every conceivable point of view. This manifests itself not only in constant shifts in trends in construction, which are made possible by the development of new construction technologies, but also in the constant development of real estate valuation procedures. The ever-increasing number of expert opinions on real estate valuation issues can also serve as a proof of the growth of the given sector. In practice, it is also possible to encounter a situation in which the contracting authority places requirements on the assessor regarding the method, methodology or even the result of the valuation. This may lead to lower objectivity and a reflection of the assessor's disproportionately strong subjective feeling in the valuation itself. One of the tools to eliminate these adverse effects is the development of uniform methodologies and procedures for valuation, which on the one hand sufficiently balances the specificity of the property under consideration and on the other hand ensures a maximum objectivity of the result. This can be achieved by leveling the real estate market environment, suppressing subjective influences or eliminating errors that may have been unintentionally caused in preceding expert opinions due to insufficient research in the entire field. At this moment, the effect of the scientific basis behind the whole issue of real estate valuation is evident, which, in this respect, is a deterministic parameter of the final value of the valued real estate [1].

Usually, units of measure are used to determine the value of specific buildings putting their size in concrete terms. In some cases, they also supply a determinant of specificity to the buildings being valued. This is mainly the size of the built-up floor area in $\mathrm{m}^{2}\left(\mathrm{CZK} / \mathrm{m}^{2}\right)$ or the number of rooms (CZK / pc). However, today's technologies allow the use of other parameters of buildings as units of measure which distinguish individual buildings very precisely from other buildings [2]. The development of new technologies also allows, provided the cooperation of all parts of the real estate industry (construction, marketing, work of real estate agencies, etc.) to significantly accelerate all transactions related to the sale and rental of real estate, their valuation, etc. [3]. The value of buildings is also affected by their location in the landscape as such. If the valued building is located, for example, in an ecologically rich area, a higher value of buildings and adjacent land can be assumed [4]. To provide a value estimate of a building, it is also possible to use the hedonic regression model, which has already been examined many times, or also for specific buildings, data on their repeated sales [5]. The random forest method has proven to be a useful complementary tool to capture the complexity and nonlinearity of the entire set of buildings that is the subject of the valuation [6].

Using an interoperable data model for the valuation of land intended for building, national geographic data infrastructures can be extended, which could lead to mass valuation when using machine learning as a numerical processor. The prediction robustness of the values of this land increases with the quality and reliability of the input data [7].

Most often, the real estate valuation expert community uses traditional valuation methods, such as comparative, reproduction and yield methods. Modern valuation methods are not currently used to such an extent [8]. When comparing econometric and non-econometric valuation methods of buildings, the market value of the building used in determining the value of another building in a comparative econometric way was discovered to play an important role. However, when using a comparative econometric valuation method, there is a high demand for the amount of data that can be used for comparison. In practice, this can only be achieved with a sufficiently large database of data which is freely available, for example on the Internet [9]. 
Competition has a negative effect on the price range [10]. In such cases, the market price of the buildings was to be regulated by the state through its intervention [11]. With the help of statistical tests of data on the development of building prices, the effectiveness of individual buildings was examined according to the way they are used on the real estate market. There is a different level of risk of return on investment from individual buildings according to the method of their use. This is one of the consequences of the inhomogeneity of the real estate market [12]. Another determinant of the value of buildings is also the length of their service life which is already taken into account during their construction. This parameter is considered in connection with the intended use of the building, and, based on this deliberation, such construction materials are chosen that can withstand years of intensive use (e.g. floors of assembly halls, which are driven on by heavy equipment). Usually, in connection with this viewpoint, individual intervals of necessary reconstruction interventions to prolong the service life of the buildings are also planned. This also determines the life cycle costs of buildings (Building Information Modeling - BIM) (In the case of historic buildings, the relevant model is Historic Building Information Modeling - HBIM [13]). Nowadays, digital technologies can also be used for the evaluation of BIM itself, which can be used to scan a building from the interior and the exterior, and to determine its technical condition on the basis of the evaluated parameters [14]. BIM can also be used to evaluate the thermal properties of buildings. A three-dimensional model of buildings with specific heat leakage locations can be created for this purpose [15]. Therefore, it is also necessary to take into account the service life of the individual building materials used. As a consequence, it is advantageous to focus on the creation of a model, which could be used to determine the service life of individual structural elements of buildings [16] or to focus directly on the evaluation of the life of buildings as a whole on the basis of a visual assessment of the current state of a particular building which also takes into account the mechanisms of degradation of individual materials [17]. From an economic point of view, the best solution is to always determine the most optimal moment to carry out the reconstruction and extend the life of the buildings. This moment should respect the economic aspect so that the required investment is made with the greatest possible efficiency in terms of its necessary financial amount and also the greatest efficiency in terms of technical reconstruction of the building [18]. An appropriate prediction of construction life cycle costs can also reduce future economic costs of its operation [19]. The methodology of determining BIM has already been discussed by many authors and some have contributed to its modernization in the form of individual modifications etc. [20].

\section{Methods and data}

The examined set contains data on 50,000 constructions realized and executed on the territory of the Czech Republic beginning from long-time history to the present day, in a diverse construction-technical condition. The set thus contains new constructions, carried out after 2010 in excellent condition, as well as constructions carried out decades or hundreds of years ago in good maintained, but also in desolate condition intended for demolition or general reconstruction. From the point of view of the function of the buildings, the set is based on buildings with a predominant use other than residential (non-residential premises). The file does not include information on ground line constructions, but there are constructions established, for example, for educational and cultural purposes, historical buildings and monuments, church buildings, hospitals, administrative buildings, halls, chimneys, buildings that are part of higher technological units (wastewater treatment plant, etc.). 
The character of the building will be determined on the basis of the classification of the Uniform Classification of Buildings. The basic element of the valuation is the unit price of Technical and Economic Indicators (THU) which are determined on the basis of long-term statistics and price developments in construction, and are regularly published by specialized companies engaged in processing price systems in the field of construction. THU indicators are related to the unit price, i.e. CZK / unit where a unit can be represented according to its character by a cubic meter of the basic enclosed space of the building, a square meter for civil engineering or a length meter for linear structures. Unit prices of THU indicators are regularly published on the website www.stavebnistandardy.cz.

The initial data obtained this way will be further adjusted by the coefficients of the respective tenders. This coefficient represents another degree of objectification of the entire calculation, and seeks to bring unit prices as close as possible to the market reality in the Czech Republic. The coefficient is based on the survey of previous tenders for contractors / suppliers of the construction. It included all tenders with a construction theme, published in the Czech Republic in the period 2016-2018 with an expected scope of > CZK 1 million for supplies and services and $>3$ CZK million for construction work; a total of 1,161 tenders were included in the survey. The coefficient was further divided into sub-coefficients according to the nature and essence of the solved contract in relation to the definition of JKSO (Uniform classification of construction objects). The coefficient thus expresses the ratio between the originally planned (budget) price of the contract and the actual winning price in the given procedure.

\subsection{Calculation variants of the reproduction value}

The calculation of the reproduction value of all buildings can be calculated in two variants:

- Reproduction and time value of the building.

- Reproduction and time value of the building including ancillary budget costs.

The first variant of the calculation takes into account the reproduction purchase price of the building and the wear and tear of the building. In addition, the second variant of the calculation includes the relevant ancillary budget costs (costs of design work and engineering activities, costs of site location, costs of technical infrastructure and risk reserve).

Table 1. Structure for calculating the reproduction value of all buildings

\begin{tabular}{|l|l|}
\hline \multicolumn{1}{|c|}{ Calculation variant 1 } & \multicolumn{1}{c|}{ Calculation variant 2} \\
\hline Reproduction purchase price of the building & Reproduction purchase price of the building \\
\hline$\rightarrow$ taking into account the wear of the building & $\rightarrow$ taking into account the wear of the building \\
\hline & + costs of design work and engineering activities \\
\hline & + costs of site location \\
\hline & + costs of technical infrastructure \\
\hline$=$ Reproduction and time value of the building & $\begin{array}{l}=\text { risk reserve } \\
\text { including ancillary budget costs }\end{array}$ \\
\hline
\end{tabular}

Source: Own processing. 


\subsection{Technical and economic indicators}

The starting point for calculating the reproduction value of buildings is based on the technical and economic indicators of RTS, a.s., which are publicly available free of charge on the website: http://www.stavebnistandardy.cz/default.asp?Bid=6\&ID=6.

Technical and economic indicators are commonly used for valuing construction plans at the planning stage and calculating construction costs. The values of indicators were compiled on the basis of long-term statistics on prices of buildings and constructions from representative item budgets and indexation. Each price indicator has an assigned unit of measure, i.e. a unit of measure to which construction costs are related (it's just about only basic budget costs - they do not include ancillary and other costs). For buildings and halls, these are usually cubic meters of enclosed space.

This default data of RTS, a.s. (technical and economic indicators) was further adjusted by conversion coefficients of tenders based on the research team's own survey. The coefficient of tenders expresses the ratio between the expected (budget) price of the contract and the final winning (lowest bid) price of the selected tenderer. It is implicitly assumed that the tenderer submitted the tender to the tender freely, voluntarily, and is willing to implement the subject of performance for the tender price, while the tenderer behaves with due diligence and the offered price brings sufficient value from the work (covers all anticipated costs and reasonable profit). The calculation does not take into account the final price for the implementation of the contract, which may be affected by other costs during construction (more / less work), as it can be assumed that these costs were not expected and foreseeable at the time of awarding the contract and would occur another supplier.

Information on published tenders was drawn from a database managed by the Ministry of Regional Development of the Czech Republic, available online: https://www.vestnikverejnychzakazek.cz/. The main advantages of this database include a large number of orders with all files and attachments owned by the home domain and no redirection to other websites during the search or viewing of documents, as is the case with some competing databases. The Public Procurement Bulletin records public contracts with an expected scope of more than CZK 1 million for supplies and services and more than CZK 3 million for construction work.

An extensive table was created for the purpose of recording values and information from suitable public contracts. Its content consists of a horizontal axis consisting of columns: order number, region, city, contracting authority, building code, type of building, project name, operation, project description, closing date, contract closing date, estimated price (excluding VAT), final price, ratio of final and estimated price, supplier, registered office of the supplier, duration in months and source. The vertical axis then consists of individual public contracts.

Table 2. Calculated coefficients of tenders according to the use of the building

\begin{tabular}{|l|c|c|}
\hline \multicolumn{1}{|c|}{ Use of the building } & $\begin{array}{c}\text { The number of } \\
\text { records }\end{array}$ & $\begin{array}{c}\text { Coefficients of } \\
\text { tenders }\end{array}$ \\
\hline Administrative buildings & 70 & 0,9279 \\
\hline Other residential buildings & 122 & 0,8949 \\
\hline Buildings for religious activities & 41 & 0,9451 \\
\hline Buildings for industry & 43 & 0,8743 \\
\hline Buildings for social purposes & 66 & 0,9014 \\
\hline Sports buildings & 109 & 0,9504 \\
\hline
\end{tabular}




\begin{tabular}{|l|c|c|}
\hline Healthcare buildings & 175 & 0,9432 \\
\hline Garages & 41 & 0,9586 \\
\hline Historical or cultural monuments & 47 & 0,9288 \\
\hline Hotels & 36 & 0,8802 \\
\hline Museums and libraries & 73 & 0,9284 \\
\hline Schools, universities and research buildings & 338 & 0,9116 \\
\hline Total / weighted average & $\mathbf{1 1 6 1}$ & $\mathbf{0 , 9 2 0 9}$ \\
\hline
\end{tabular}

Source: Own processing.

\subsection{Determination of building wear}

The linear wear method was used to determine the wear of the buildings. For the linear method, wear increases in direct proportion to time. It is assumed that the building as a whole degrades over time. We can express this dependence by a formula:

$$
W=100 * \frac{A}{L}
$$

where

$W \ldots$ wear of the building calculated by the linear method [\%],

$A$... age of construction [years],

$L$... lifetime of the building [years].

A service life of 200 years is considered as the limit value. The reason is the maximum permissible service life of foundations, vertical structures, ceilings and stairs in relation to Table No. 7, Annex No. 15, Decree No. 3/2008 Coll. (so-called valuation decrees) on the implementation of certain provisions of Act No. 151/1997 Coll. on property valuation, as amended. This period is just 200 years.

In determining the service life of buildings, it was based on Annex No. 15 to Decree No. $3 / 2008$ Coll. (so-called valuation decrees), other information sources and the experience of the research team. The table of building lifetimes distinguishes JKSO (uniform classification of construction objects, Czech national regulation) in the level - the field of the building object ( $1^{\text {st }}$ to $3^{\text {rd }}$ place of the numerical code) and at the same time the building material of the load-bearing structures.

Table 3. Lifespan of buildings in years

\begin{tabular}{|l|l|c|c|c|c|c|c|c|c|c|}
\hline \multirow{2}{*}{$\begin{array}{c}\text { JKSO (uniform classification of } \\
\text { construction objects) }\end{array}$} & \multicolumn{6}{c|}{ Structural and material characteristics of load- } \\
\cline { 3 - 11 } & $\mathbf{1}$ & $\mathbf{2}$ & $\mathbf{3}$ & $\mathbf{4}$ & $\mathbf{5}$ & $\mathbf{6}$ & $\mathbf{7}$ & $\mathbf{8}$ & $\mathbf{9}$ \\
\hline 801 & Civil engineering buildings & 200 & 150 & 200 & 100 & 100 & 75 & 70 & 80 & 80 \\
\hline 802 & Civil engineering halls & 150 & 150 & 150 & 100 & 100 & 75 & 70 & 80 & 80 \\
\hline 803 & Residential buildings & 200 & 150 & 200 & 100 & 100 & 75 & 70 & 80 & 80 \\
\hline 812 & Buildings for production and services & 150 & 150 & 150 & 100 & 100 & 75 & 70 & 80 & 80 \\
\hline
\end{tabular}

Source: Own processing, related legal and technical regulations. 
For a complete understanding of the above table, it is further stated that the JKSO classification distinguishes a total of 9 types of building materials of vertical load-bearing structures of buildings:

- 1 - vertical load-bearing structure made of bricks and blocks,

- 2 - vertical load-bearing structure monolithic concrete bar,

- 3 - vertical load-bearing structure monolithic concrete surface,

- 4 - vertical load-bearing structure assembled from concrete bar parts,

- 5 - vertical load-bearing structure assembled from concrete surface parts,

- 6 - vertical load-bearing structure mounted from spatial cells,

- 7 - vertical metal supporting structure,

- 8 - vertical wooden and wood-based load-bearing structure,

- 9 - vertical load-bearing structure made of other materials.

\subsection{Overall assessment of the condition of the building}

A parameter that evaluates the technical condition of the building is also included in the calculation. A total of 5 categories of the overall assessment of the condition of the building are distinguished, from the new building to the state of emergency. For each category, a building condition coefficient is assigned, which multiplies the basic technical and economic indicator.

Table 4. Overall assessment of the condition of the building and risk reserve

\begin{tabular}{|l|c|c|}
\hline $\begin{array}{c}\text { Overall assessment of the condition } \\
\text { of the building }\end{array}$ & $\begin{array}{c}\text { Coefficient of } \\
\text { building condition }\end{array}$ & $\begin{array}{c}\text { Risk percentage } \\
{[\%]}\end{array}$ \\
\hline Brand new building, max. age 5 years & 1,00 & 10,00 \\
\hline Excellent & 0,95 & 11,25 \\
\hline Quite satisfactory & 0,90 & 12,50 \\
\hline Requires renovation & 0,80 & 13,75 \\
\hline Emergency (ruin) & 0,70 & 15,00 \\
\hline
\end{tabular}

Source: Own processing.

\subsection{Risk reserve}

The risk reserve is used to cover unexpected expenses during construction. It is considered in the range of $7-10 \%$ for new buildings, $10-15 \%$ for reconstructions. The basis for the calculation is the reproduction purchase price of the building. The previous table is used for the calculation, which determines the risk percentage depending on the overall assessment of the condition of the building.

\subsection{Costs of design work and engineering activities}

To calculate the costs of design work and engineering activities, it is necessary to include the following three performance phases:

- construction management phase (planning),

- construction phase,

- phase after construction completion. 
According to the website http://cenyzaprojekty.cz/sazebnik.html, these three phases represent $85 \%$ of the total costs of project work and engineering activities. This percentage is the same for all construction categories and all performance zones.

Costs of design work and engineering activities are calculated using the appropriate performance zone for each building. From the following table, the appropriate percentage will be used to calculate the fee.

Table 5. Cut-out from the percent table for the calculation of the costs of design work and engineering activities

\begin{tabular}{|r|c|c|c|c|c|}
\hline Eligible costs & \multicolumn{5}{|c|}{ Performance zone by category of building } \\
\hline CZK & 1 & 2 & 3 & 4 & 5 \\
\hline & \multicolumn{5}{|c|}{ Percentage for calculating the fee } \\
\hline 0 & 8,87 & 10,71 & 13,25 & 15,46 & 17,14 \\
\hline 1000000 & 8,24 & 9,91 & 11,99 & 14,03 & 15,75 \\
\hline 2000000 & 7,88 & 9,51 & 11,49 & 13,38 & 15,00 \\
\hline 3000000 & 7,64 & 9,15 & 11,05 & 12,93 & 14,47 \\
\hline 4000000 & 7,46 & 8,92 & 10,77 & 12,59 & 14,08 \\
\hline 5000000 & 7,31 & 8,74 & 10,54 & 12,33 & 13,77 \\
\hline$\ldots$ & $\ldots$ & $\ldots$ & $\ldots$ & $\ldots$ & $\ldots$ \\
\hline
\end{tabular}

Source: Performance and fees regulations (ČKA, ČKAIT), own processing.

\subsection{Costs of site location}

The costs associated with the location of the building include the costs of operational and social equipment of the construction site, territorial influences, extremely difficult working environment. This item includes costs that are not valued within the costs of construction objects. The costs associated with the location of the building can be, for example:

- $\quad$ site equipment costs,

- costs caused by operational influences (for example, the operation of the investor, third parties, road, rail, urban traffic near the construction site, harmful environment),

- costs caused by areas with difficult production conditions,

- costs related to the impact of extreme climatic conditions,

- costs caused by extremely difficult traffic conditions,

- costs of necessary transport of the supplier's employees to the workplace and back,

- off-site transport costs (above the average costs included in the cost of construction sites or for selected materials),

- costs arising from the title of work on protected monuments (reduction of staff performance due to slower and more careful work).

The costs of site location is determined by a percentage rate that ranges from 2 to $5 \%$ of the value of the basic technical and economic indicator and depends on the size of the building. The larger the building, the smaller the percentage.

The function is used for the calculation, which determines the percentage of costs of site location depending on the size of the enclosed space of the building. For individual categories 
of the enclosed space of the building in the interval $<0 \mathrm{~m}^{3} ; 100,000 \mathrm{~m}^{3}>$, the percentage rate of costs of site location is determined using the linear function:

$$
y=-a x+5=\frac{3}{100000}+5
$$

where

$100,000 \ldots$ is the upper limit of the built-up area of the building.

In the case of a built-up area of a building larger than $100,000 \mathrm{~m}^{3}$, a constant percentage rate of $2 \%$ is considered.

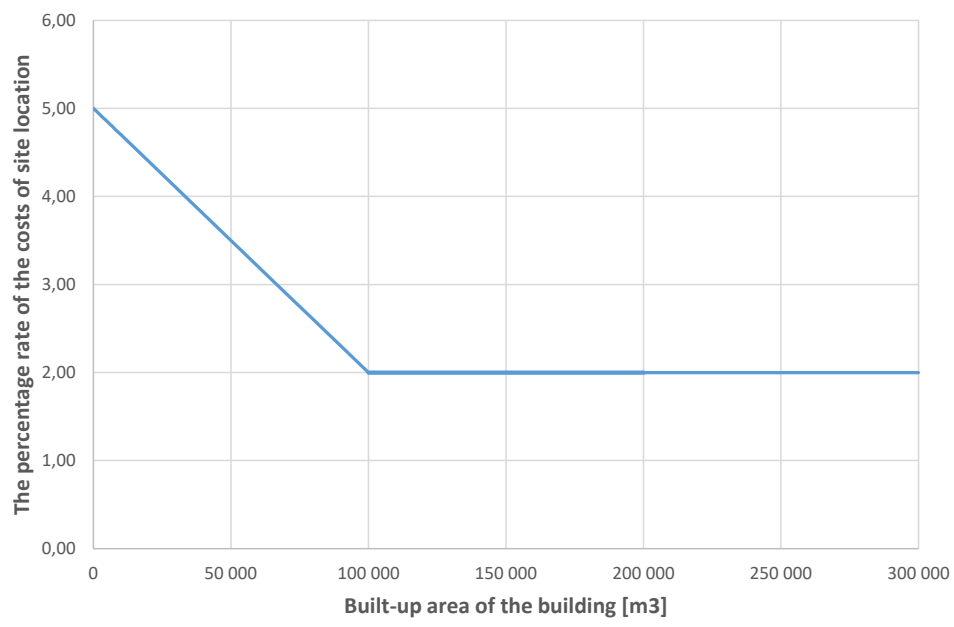

Fig. 1. Dependence of the percentage rate of the costs of site location on the size of the enclosed space of the building

\subsection{Costs of technical infrastructure}

The costs of the technical infrastructure of the building include the costs of creating the electricity connection, water supply, sewerage and gas, communications, fencing and landscaping. The value in the range of $2 \%$ to $3.5 \%$ of the reproduction value of the building is considered (even the connections and other technical infrastructure wear out over time) and depends on the size of the building. The larger the building, the smaller the percentage. 


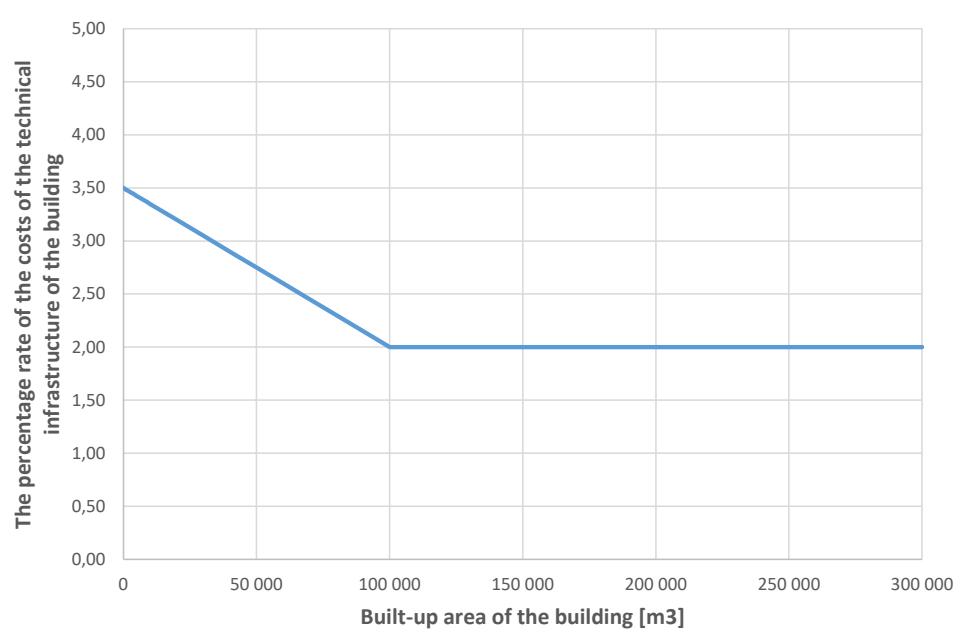

Fig. 2. Dependence of the percentage rate of the costs of the technical infrastructure of the building on the size of the enclosed space of the building

\section{Results}

By performing the procedure described above, the results shown in the table below were obtained:

Table 6. Determination of the reproduction price of buildings for individual groups

\begin{tabular}{|c|c|c|c|c|}
\hline $\begin{array}{c}\text { Group of construction } \\
\text { objects }\end{array}$ & $\begin{array}{l}\text { Amount of } \\
\text { constructions } \\
\text { in the group }\end{array}$ & $\begin{array}{c}\text { Average } \\
\text { wear }(\%)\end{array}$ & $\begin{array}{c}\text { Determined } \\
\text { reproduction price } \\
\text { excluding ancillary } \\
\text { budgetary costs }\end{array}$ & $\begin{array}{c}\text { Determined } \\
\text { reproduction price } \\
\text { including ancillary } \\
\text { budgetary costs }\end{array}$ \\
\hline $\begin{array}{c}\text { Civil engineering } \\
\text { buildings }\end{array}$ & 9015 & 56,3 & $\begin{array}{c}19819942918 \\
\text { CZK }\end{array}$ & $\begin{array}{c}33390530687 \\
\text { CZK }\end{array}$ \\
\hline Residential buildings & 11967 & 49,5 & $\begin{array}{c}80631263420 \\
\text { CZK }\end{array}$ & $\begin{array}{c}122543340070 \\
\text { CZK }\end{array}$ \\
\hline Healthcare buildings & 642 & 35,1 & $\begin{array}{c}17335769709 \\
\text { CZK }\end{array}$ & $\begin{array}{c}25054084116 \\
\text { CZK }\end{array}$ \\
\hline Educational buildings & 5463 & 37,2 & $\begin{array}{c}116915843702 \\
\text { CZK }\end{array}$ & $\begin{array}{c}168757599414 \\
\text { CZK }\end{array}$ \\
\hline $\begin{array}{l}\text { Science, culture and } \\
\text { research buildings }\end{array}$ & 5373 & 46,6 & $\begin{array}{c}37093549320 \\
\text { CZK }\end{array}$ & $\begin{array}{c}57493214049 \\
\text { CZK }\end{array}$ \\
\hline Sports buildings & 2031 & 26,0 & $\begin{array}{c}31269541757 \\
\text { CZK }\end{array}$ & $\begin{array}{c}43443075511 \\
\text { CZK }\end{array}$ \\
\hline Administrative buildings & 3234 & 43,7 & $\begin{array}{c}31627415090 \\
\text { CZK }\end{array}$ & $\begin{array}{c}48677791405 \\
\text { CZK }\end{array}$ \\
\hline $\begin{array}{c}\text { Buildings for } \\
\text { accommodation and } \\
\text { recreation }\end{array}$ & 1334 & 41,6 & $4098573291 \mathrm{CZK}$ & $6164947634 \mathrm{CZK}$ \\
\hline $\begin{array}{l}\text { Buildings for trade and } \\
\text { catering }\end{array}$ & 1334 & 34,8 & $6383892756 \mathrm{CZK}$ & $9623503822 \mathrm{CZK}$ \\
\hline Industrial buildings & 2393 & 30,8 & $8711032908 \mathrm{CZK}$ & $\begin{array}{c}12840100740 \\
\text { CZK }\end{array}$ \\
\hline $\begin{array}{l}\text { Buildings for agricultural } \\
\text { production and animal } \\
\text { husbandry }\end{array}$ & 478 & 49,4 & $1107273661 \mathrm{CZK}$ & $1988613494 \mathrm{CZK}$ \\
\hline
\end{tabular}




\begin{tabular}{|c|c|c|c|c|}
\hline $\begin{array}{l}\text { Buildings for transport } \\
\text { and communication }\end{array}$ & 1141 & 34,2 & $1280144515 \mathrm{CZK}$ & $1987182872 \mathrm{CZK}$ \\
\hline $\begin{array}{l}\text { Garages, buildings for } \\
\text { repair and maintenance of } \\
\text { vehicles, machinery and } \\
\text { equipment }\end{array}$ & 2704 & 35,1 & $4832890636 \mathrm{CZK}$ & $6998214028 \mathrm{CZK}$ \\
\hline Storage buildings & 2891 & 43,6 & $7639371538 \mathrm{CZK}$ & $\begin{array}{c}12328699922 \\
\text { CZK }\end{array}$ \\
\hline Total & 50000 & -- & $\begin{array}{c}368746505228 \\
\text { CZK }\end{array}$ & $\begin{array}{c}551290897771 \\
\text { CZK } \\
\end{array}$ \\
\hline
\end{tabular}

Source: Own processing.

From the table above, it is obvious that the total reproduction value of the examined real estate sample excluding ancillary budgetary costs is $368746505228 \mathrm{CZK}$ and including the ancillary budgetary costs then 551290897771 CZK.

\section{Conclusion}

The presented paper introduced its own comprehensive methodology for determining the reproductive value of a significant internally inhomogeneous set of buildings. The methodology introduced a method of approximating budget costs and list prices to market reality, while this coefficient may be applicable for other contracting parties as well. Furthermore, the authors introduced a unique way of determining the ancillary costs of construction, as a necessary cost element in construction activities. This method can also be further reproduced and thus contribute to the improvement of the initial estimates of construction costs. The application of this element does not depend on local conditions, and thus the given method can be applied across markets and depends on the actual mass of the building (enclosed space). The proposed methodology was subsequently applied to a set of 50,000 randomly selected buildings in the Czech Republic. The goal of the paper was fulfilled. The authors see a further research possibility in the focus of the scientific community's interest on the pricing factor of location, resp. locality, i.e. a stronger emphasis on regional influence in the set reproduction price. The outputs of the paper can also be used by the public sector in defining government housing policy.

\section{References}

1. U. Ozdilek, Scientific basis of value and valuation. Journal of revenue and pricing management, 18(3), 266-277 (2019)

2. J. Bin, B. Gardiner, E. Li, Z. Liu, Multi-source urban data fusion for property value assessment: A case study in Philadelphia. Neurocomputing, 404, 70-83 (2020)

3. A. Saull, A. Baum, F. Braesemann, Can digital technologies speed up real estate transactions? Journal of property investment \& finance, 38(4), 349-361 (2020)

4. A. Binter, K. Krol, M. Frosik, M. Furczon, Ecological Considerations in Real Estate Valuation. Journal of ecological engineering, 21(5), 47-55 (2020)

5. A. Oust, S. N. Hansen, T. R Pettrem, Combining Property Price Predictions from Repeat Sales and Spatially Enhanced Hedonic Regressions. Journal of real estate finance and economics, 61(2), 183-207 (2020)

6. J. Hong, H. Choi, W.S. Kim, A house price valuation based on the random forest approach: the mass appraisal of residential property in South Korea. International Journal of Strategic Property Management, 24(3), 140-152 (2020) 
7. A. C. Aydinoglu, R. Bovkir, I. Colkesen, Implementing a mass valuation application on interoperable land valuation data model designed as an extension of the national GDI. Survey review, [Early Access] (2020)

8. R. B. Abidoye, M. Junge, T. Y. M. Terence, T. B. Oyedokun, M. L. Tipping, Property valuation methods in practice: evidence from Australia. Property management, 37(5), 701-718 (2019)

9. J. Zyga, Object and objective of property appraisal and their effects on valuation methods and databases. Geodetski vestnik, 63(1), 92-103 (2019)

10. K. S. Gerardi, A. H. Shapiro, Does Competition Reduce Price Dispersion? New Evidence from the Airline Industry. Journal of Political Economy, 117(1), 1-37 (2009)

11. J. B. H. Yap, X. H. Ng, Housing affordability in Malaysia: perception, price range, influencing factors and policies. International Journal of Housing Markets and Analysis, 11(3), 476-497 (2018)

12. F. Almudhaf, A. J. Hansz, Random Walks and market efficiency: Evidence prom real estate investment trusts (REIT) subsectors. International Journal of Strategic Property Management 22(2), 81-92 (2018)

13. A. Mol, M. Cabaleiro, H. S. Sousa, J. M. Branco, HBIM for storing life-cycle data regarding decay and damage in existing timber structures. Automation in Construction, 117, Art. No. 103262 (2020)

14. A. G. Mohamed, M. R. Abdallah, M. Maryouk, BIM and semantic web-based maintenance information for existing buildings. Automation in Construction, 116, Art. No. 103209 (2020)

15. D. Utkucu, H. Sozer, Interoperability and data exchange within BIM platform to evaluate building energy performance and indoor comfort. Automation in Construction, 116, Art. No. 103225 (2020)

16. C. Chai, J. De Brito, P. L. Gaspar, A. Silva, Statistical modelling of the service life prediction of painted surfaces. International Journal of Strategic Property Management, 19(2), 173-185 (2015)

17. C. Marques, J. de Brito, A. Silva, Application of the factor method to the service life prediction of etics. International Journal of Strategic Property Management, 22(3), 204$222(2018)$

18. A. Farahani, H. Wallbaum, J. O. Dalenback, Optimized maintenance and renovation scheduling in multifamily buildings - a systematic approach based on condition state and life cycle cost of building components. Construction Management and Economics, 37(3), 139-155 (2019)

19. J. Lee, H. Yang, J. Lim, T. Hong, J. Kim, K. Jeong, BIM-based preliminary estimation method considering the life cycle cost for decision-making in the early design phase. Journal of Asian Architecture and Building Engineering, 19(4), 384-399 (2020)

20. D. Wieczorek, E. Plebankiewicz, K. Zima, Model estimation of the whole life cost of a building with respect to risk factors. Technological and Economic Development of Economy, 22(1), 20-38 (2019)

21. D. Macek, M. Kosina, Specifications of M\&E requirements in the BIM model in the context of use for facility management. 3rd International Conference on Engineering Sciences and Technologies, ESaT 2018, 425-430 (2018)

22. T. McGough, J. Berry, Pricing risk and its use in modelling real estate market yields. Journal of Property Investment and Finance, 38(5), 419-433 (2020)

23. W. Kuang, C. Chen, Q. Wang, Home purchase restriction, real estate investment, and corporate innovation. Frontiers of Business Research in China, 14(1) (2020) 